Article

\title{
Quantification of Fog Water Collection in Three Locations of Tenerife (Canary Islands)
}

\author{
Axel Ritter ${ }^{1, *}$, Carlos M. Regalado ${ }^{2}$ and Juan Carlos Guerra ${ }^{3}$
}

1 Area of Agroforestry Engineering, University of La Laguna, Carretera de Geneto, 2, La Laguna, Tenerife 38200, Spain

2 Department of Soils and Irrigation, Canarian Crop Research Institute (ICIA), P.O. Box 60 La Laguna, Tenerife 38200, Spain; E-Mail: cregalad@icia.es

3 Department of Physics, University of La Laguna, Astrofísico Francisco Sánchez s/n, La Laguna 38271 Tenerife, Spain; E-Mail: jcguerra@ull.es

* Author to whom correspondence should be addressed; E-Mail: aritter@ull.es; Tel.: +34-922-318-548; Fax: +34-922-318-562.

Academic Editor: María del Pino Palacios Díaz

Received: 10 April 2015 / Accepted: 15 June 2015 / Published: 26 June 2015

\begin{abstract}
We present the results of fog water collection obtained with cylindrical fog gauges at three locations on the northern side of Tenerife island (Spain): La Esperanza (1093 m a.s.1.), Taborno (1015 m a.s.1.), and El Gaitero (1747 m a.s.1.). Concomitant meteorological variables were also measured. We show that fog precipitation was more frequent than rainfall. However, the volumes and frequency of daily fog water collection varied among the three studied sites, usually not exceeding $10-40 \mathrm{~L} \mathrm{~d}^{-1} / \mathrm{m}^{2}$ of collecting surface. In La Esperanza, fog water harvesting occurred frequently, but was considerably lower than in the other two locations. However, while in Taborno fog water collection episodes were distributed throughout the period, in El Gaitero these were mainly concentrated in two periods, during autumn and winter 2012-2013. The study of the relationships between daily fog water yields and the averages of meteorological variables did not show any clear trend, but it suggested that the greater volumes of collected fog water were logically associated with higher wind speeds and lower solar radiation conditions. Fog water collection in La Esperanza and in Taborno typically occurred within a similar temperature interval $\left(7.5-12.5^{\circ} \mathrm{C}\right)$, while in El Gaitero the phenomenon was associated with a lower temperature range $\left(2.5-10^{\circ} \mathrm{C}\right)$.
\end{abstract}


Keywords: cloud belt; fog; fog collection; precipitation; temperature inversion

\section{Introduction}

The vertical thermic structure of the atmosphere in the Macaronesian region is characterized by an increase in temperature with height. This results from the atmospheric subsidence associated with the descending branch of the general circulation northern Hadley cell [1]. Such a temperature inversion, together with the orographic lifting of moist air masses, driven by the trade winds towards islands with higher profile, is responsible for the establishment of a stable stratocumulus layer between 900 and $1500 \mathrm{~m}$ a.s.1. in the Canary Islands (Spain). Font Tullot [2] established the monthly average altitude of the subsidence inversion using a 40 year-dataset, from ground-level observatories at different altitude sites in the volcanic island of Tenerife (Canary Islands), showing a clear seasonal variation of the inversion layer: typically $1600 \mathrm{~m}$ a.s.1. in winter and $1200 \mathrm{~m}$ a.s.1. in summer. More recent studies using regular radiosonde data have confirmed these findings [3,4]. This leads to the presence of frequent low clouds or fog mainly on the northern slopes of the western Canary Islands. Despite these foggy conditions prevailing in the Canarian cloud forests, it is not yet clear whether horizontal precipitation represents a significant water input [5], or by contrast the role of fog is to reduce the vegetation water losses by evapotranspiration [6,7]. Water from wind driven fogs can be also trapped artificially, for example, by mesh screens displayed in wind exposed areas with frequent presence of clouds [8-10]. It is worth mentioning though that artificially collected fog water values are neither comparable to rainfall (both units and scale are different), nor can they be extrapolated straightforwardly to fog water captured by the vegetation [11]. Unlike the dew phenomenon, which implies water vapor condensation, fog water capture does not involve water phase changes. This basically consists in collecting, mainly by impaction, the water droplets $(0.1-200 \mu \mathrm{m}$ in diameter; typically $50 \mu \mathrm{m}$; $[12,13])$ that travel suspended in a mass of water vapor saturated air. Such fog liquid water content represents only an amount of the order of $0.1-1.25 \mathrm{~g} \cdot$ water per $\cdot \mathrm{m}^{3}$ air [14], and it is determined by the density and size distribution of the fog droplets [13-15]. Liquid water content thus determines the potential (maximum) volume of water that can be obtained from the fog.

In order to capture water droplets contained in the fog, these have to impact on some surface that acts as an obstacle that stands in its flowing path. Consequently, collection efficiency depends greatly on the speed and size of the water droplets (specifically the Stokes and Reynolds numbers), as well as the geometry and wettability of the obstacle, and therefore the characteristics of the impacting surface [16,17]. Given these requirements, i.e., sufficient wind speed, high liquid water content, appropriate size of the impaction elements and fog droplets, different collectors can be designed to capture fog water artificially [18-20]. Artificial fog gauges are usually either cylindrical (thus independent of wind direction) or flat structures provided with some kind of mesh or vertical filament array, where fog droplets impinge and join to form larger drops. These fall under the influence of gravity into a trough or gutter, from which are conveyed to a storage tank [21-23]. Usually artificial fog collectors have typical capturing surfaces of the order of a few square meters $\left(0.5-10 \mathrm{~m}^{2}\right)$. Given the rather low water yields usually obtained by artificial means, low-tech designs such as framed mesh 
screens held by two poles [24] have prevailed over more sophisticated prototypes in practical applications. Accordingly, their maintenance is minimal, however the mesh and foundations may be damaged because of wind forces [25]. Other disadvantages include their dependence on the meteorological conditions and the topography of the area, and thus the reduced reliability of artificial fog water collectors when a constant fog water supply is desired [26].

Several studies around the World have reported daily fog water collection yields ranging from 0.2 to $4 \mathrm{~L} \cdot \mathrm{m}^{-2} \cdot \mathrm{d}^{-1}$ (in Table 1 , [22]). As commented above, the collection capacity of a particular mesh structure depends on its design [17], but it is also strongly influenced by the speed of winds blowing normal to the collection surface, thus the comparison or extrapolation of these values to other scenarios may be challenging, because different fog conditions, collection periods, and mesh designs were used in these studies.

Previous experiences of artificial fog capture carried out in the Canary Islands have used either flat [6,27-29] or cylindrical [30-32] fog water collectors. The Grunow fog water gauge consists of a wire mesh cylinder such that its height is twice the diameter, and where its vertical cross-sectional area equals that of the orifice of the rain gauge attached to it below. Thus, in this particular case, expressing fog yield in terms of the mesh cross-sectional area $\left(\mathrm{L} \cdot \mathrm{m}^{-2}\right)$ coincides with that referred to horizontal area or water depth (mm). Kämmer [31] also measured rainfall with a Hellmann rain gauge identical to that used in the Grunow-type fog collector, and thus referred to the "measurement difference" between the rain gauge and the Grunow fog collector (both expressed in mm units) as the fog contribution. However, these results must be taken with care since, as noticed by [17], wind driven rain falling with an angle would render higher water volumes in the Grunow collector with respect to the Hellman rain gauge due to the increased catching area of the mesh in the former (see also [6]). Kämmer [31] measured both cumulative rainfall and fog water from 1 January 1971 until mid March 1972, with a two-day (or even daily) frequency, at 22 sites in the east part of Tenerife between 255 and $2020 \mathrm{~m}$ a.s.1. The reported yearly "measurement differences" during 1971 varied from the $5090 \mathrm{~mm}$ at the highest site (Montaña Ayosa) and the $74 \mathrm{~mm}$ and $77 \mathrm{~mm}$ at $442 \mathrm{~m}$ a.s.l. (El Sauzal) and the lowest site, respectively. Earlier studies in the Canaries, to this of Kämmer [31], that also used a Grunow fog collector, are those reported in [30] in La Cumbre (Gran Canaria) at $1600 \mathrm{~m}$ a.s.l. and in Lanzarote at four sites below $325 \mathrm{~m}$ a.s.l. Fog water collection was negligible in Lanzarote while $107 \mathrm{~L} \mathrm{~m}^{-2}$ fog water were measured in La Cumbre solely during days with no rainfall from April to December 1965. L.M. Santana Pérez, at the Instituto Nacional para la Conservación de la Naturaleza (ICONA), used both flat and unsheltered cylindrical fog gauges to estimate fog precipitation in the western Canary Islands. The mesh cylindrical fog collectors $(0.28 \mathrm{~m}$ diameter and $1 \mathrm{~m}$ height $)$ were attached to an $800 \mathrm{~cm}^{2}$ orifice totalizing rain gauge placed $2.5 \mathrm{~m}$ above ground. Measurements were carried out with this device at nine sites in Tenerife between 1050 and $1600 \mathrm{~m}$ a.s.l. during 1985, reporting yearly fog water volumes around 50-300 L [32]. Since the collectors were unsheltered, these fog water volumes may also include rainfall. After discounting the rainfall and dividing by the cross sectional area of the cylindrical gauge, we obtained a rough estimate of 100-900 $\mathrm{L} \mathrm{m}^{-2}$ year $^{-1}$ fog water yield.

The quality of the data of the above-discussed studies is rather limited, since fog water volumes were measured manually as totalizing variables, using the equipment available at that time. The objective of this paper is to further contribute to the knowledge of fog water capture in Tenerife, using modern automatic recording meteorological instruments, in order to determine in what circumstances 
and under what conditions fog can be considered a source of usable water. In particular, it aims to investigate to what extent the weather conditions in the north of the Island and the number of events and volumes of artificially collected fog water could allow this resource to be used for agroforestry purposes, in a place where rainfall is scarce $\left(600-700 \mathrm{~mm}_{\text {year }}{ }^{-1}\right)$.

\section{Materials and Methods}

Three places on the north side of the island of Tenerife were selected for monitoring micrometeorological variables and fog collection in the areas known as La Esperanza, Taborno and El Gaitero (Figure 1a). The site named as La Esperanza is located on top of a regulatory drinking water closed reservoir in the town of El Rosario at an altitude of $1093 \mathrm{~m}$ a.s.1. (28 $\left.26^{\prime} 37.75^{\prime \prime} \mathrm{N}, 16^{\circ} 22^{\prime} 40.29^{\prime \prime} \mathrm{W}\right)$. It is N-NW oriented and often affected by fog events. The natural vegetation of the area is pine (Pinus canariensis Smith.) and wax myrtle-tree heath ("fayal-brezal" in Spanish with Erica arborea L. and Myrica faya Ait. as predominant species). In the vicinity, there are also many potato fields. The site named Taborno is located in the Anaga Mountains in the northeast of the Island, and next to the mountain known as Cruz de Taborno. It represents the highest location within the Anaga Rural Park, at a height of $1015 \mathrm{~m}$ a.s.1. $\left(28^{\circ} 32^{\prime} 9.61^{\prime \prime} \mathrm{N}, 16^{\circ} 16^{\prime} 8.91^{\prime \prime} \mathrm{W}\right)$. The geographic location of this site, as well as the fact of being located in the highest part of the Rural Park (being thus exposed to the prevailing direction of NE trade winds), ensures that most of the year it is affected by the stratocumulus layer resulting from the subsidence inversion. The vegetation of the area is wax myrtle-tree heath with abundant epiphytic lichens, which is a characteristic of fog-exposed forests. The site known as El Gaitero is within a pine forest located on the "Pedro Gil" ridge at $1747 \mathrm{~m}$ a.s.l. and N-NW oriented (2823'40.92" N, 16² $\left.25^{\prime} 59.88^{\prime \prime} \mathrm{W}\right)$.

At the first two locations, Taborno and La Esperanza, micrometeorological variables were measured on a 7-m height scaffolding tower instrumented for taking measurements at 1-min intervals and stored as averages or cumulative totals every 15 min using a Combilog datalogger (Up GmbH, Cottbus, Germany). Monitored variables were: temperature and relative humidity (HMP45C thermo-hygrometer, Campbell Scientific Ltd., Loughborough, UK), global radiation (SKS 1110 pyranometer, Skye Instruments Ltd., Powys, UK), wind speed (A100R anemometer, Campbell Scientific Ltd.), wind direction (W200P wind vane, Campbell Scientific Ltd.) and rainfall (Rain-O-Matic Professional $0.2 \mathrm{~mm}$ resolution spoon tipping raingauge from Pronamic Bekhøi International Trading Engineering Co. Ltd., Silkeborg, Denmark). At the three locations, fog water was captured with cylindrical wire-harp gauges similar to the ASRC (Atmospheric Science Research Center, State University of New York) string collector [33,34], $46 \mathrm{~cm}$ high and $20 \mathrm{~cm}$ outer diameter, thus having a cross sectional collecting surface of $920 \mathrm{~cm}^{2}(=46 \times 20)$. These gauges were constructed with two concentric arrays of a single vertical nylon fishing line $(0.5 \mathrm{~mm}$ diameter $)$ strung back and forth between the teeth of two circular band saw blades used as guides (rendering $2 \mathrm{~mm}$ spacing between nylon filaments) for each of the two filament array banks. A funnel at the bottom was connected via a hose to a Rain-O-Matic tipping bucket gauge for recording the volumes of fog water collected (Figure 1b). 


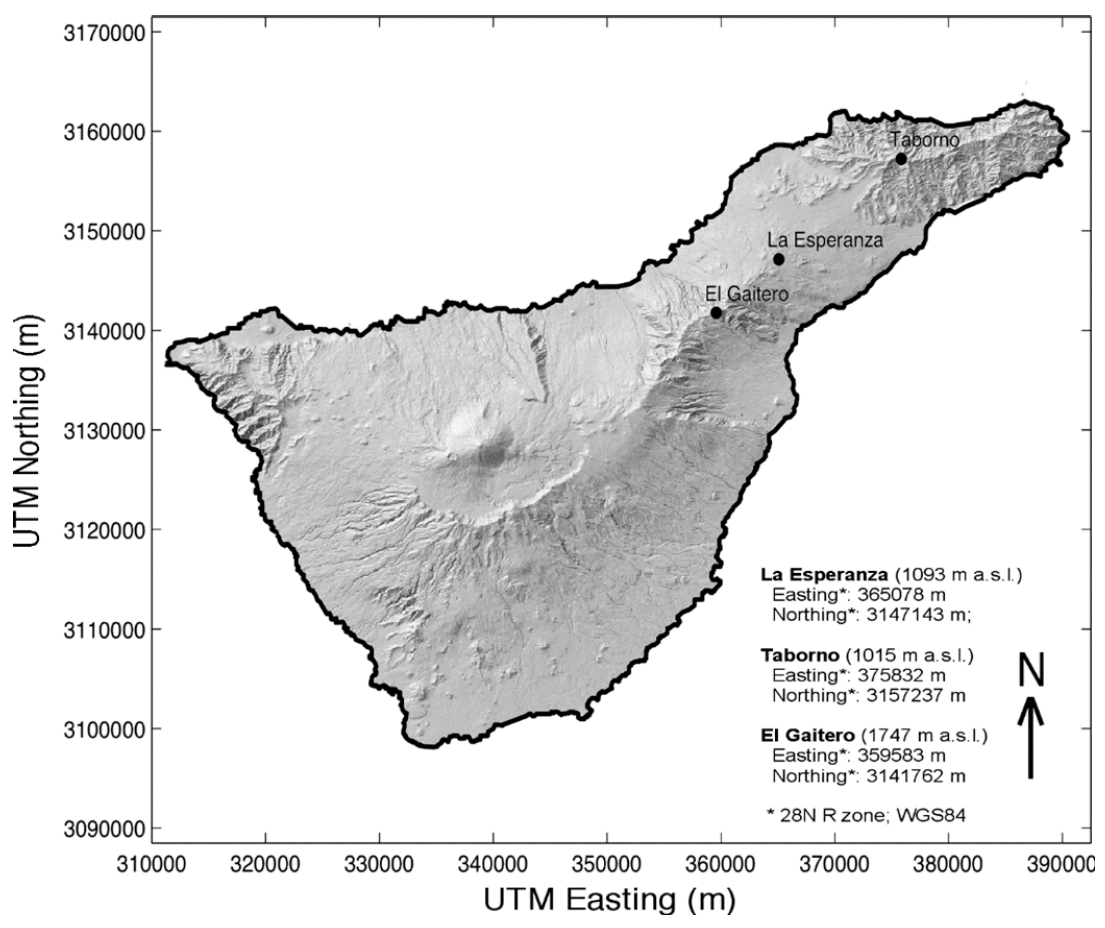

(a)

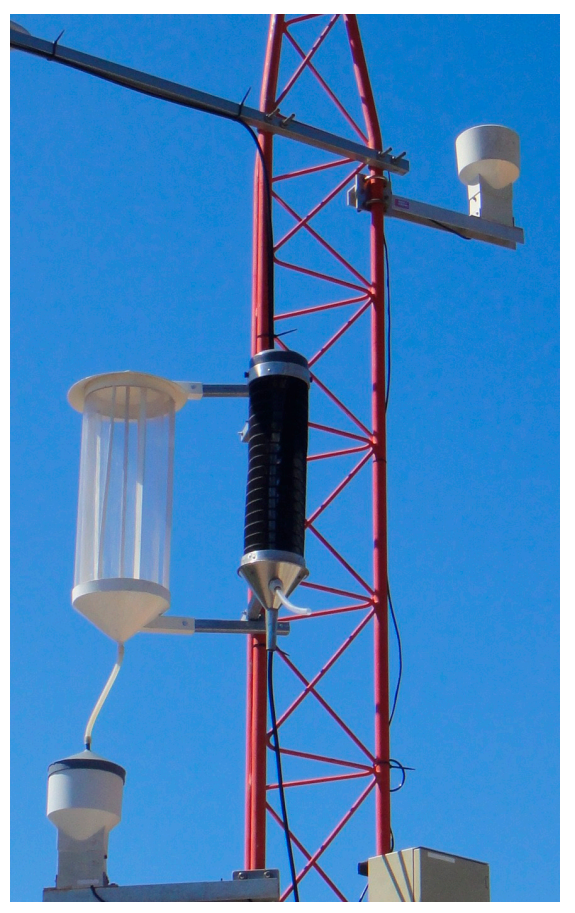

(b)

Figure 1. (a) Location of the experimental sites, and (b) the modified Juvik-type (black) and cylindrical wire-harp (white painted) fog water gauges.

Measured volumes were referred to the effective impact mesh surface $\left(920 \mathrm{~cm}^{2}\right)$, i.e., for expressing them as $\mathrm{L} \mathrm{m}^{-2}$ of vertical surface. Although the structure has a roof cover $(27.5 \mathrm{~cm}$ diameter), which minimizes the collection of rainfall during events of mixed precipitation (rainfall + fog), possible fog events during rainy periods were discarded from the total amount of collected fog water, in order to avoid accounting for spurious measurements as a result of wind blown rainfall drops that could impact obliquely onto the collector surface. When compared with flat mesh fog collectors, the wire harp is expected to show increased collection efficiency, depending on the number of filament arrays, strand diameter and filament interspacing [35]. This is due to reduced clogging in the wire harp as compared to that of mesh openings by coalesced fog water, because of a lower adhesion in the former and thus faster evacuation of trapped droplets from the system by gravity. The other issue to take into consideration is re-entrainment or detachment of deposited fog water droplets back into the wind stream [36]. Thus, at high wind speeds, the flat wire harp is expected to be less efficient than mesh type collectors because droplets will be easily blown off from the vertical filaments. By contrast, at low wind speeds, since water droplets are removed much faster from the system in the wire harp, the probability of re-entrainment would be reduced. In our case, water loses due to re-entrainment were reduced because of the double bank of filaments employed and the cylindrical geometry, which would make recapturing of escaped water droplets possible. Curvature of the collecting surface is also to be taken into account [37]. Thus the phenomenon is rather complex and this may explain contradictory results obtained in previous studies, which compared different fog collectors [19,20]. When compared with a modified Juvik-type fog gauge (Figure 1b), previously described in [19], the cylindrical wire-harp fog collector used in this study showed similar collection yields, although some diversion is observed for larger values (Figure 2). We hypothesize this may me due to "clogging" of the mesh 
and/or re-entrainment of water droplets in the modified Juvik-type gauge (see discussion above), but further analysis is necessary.

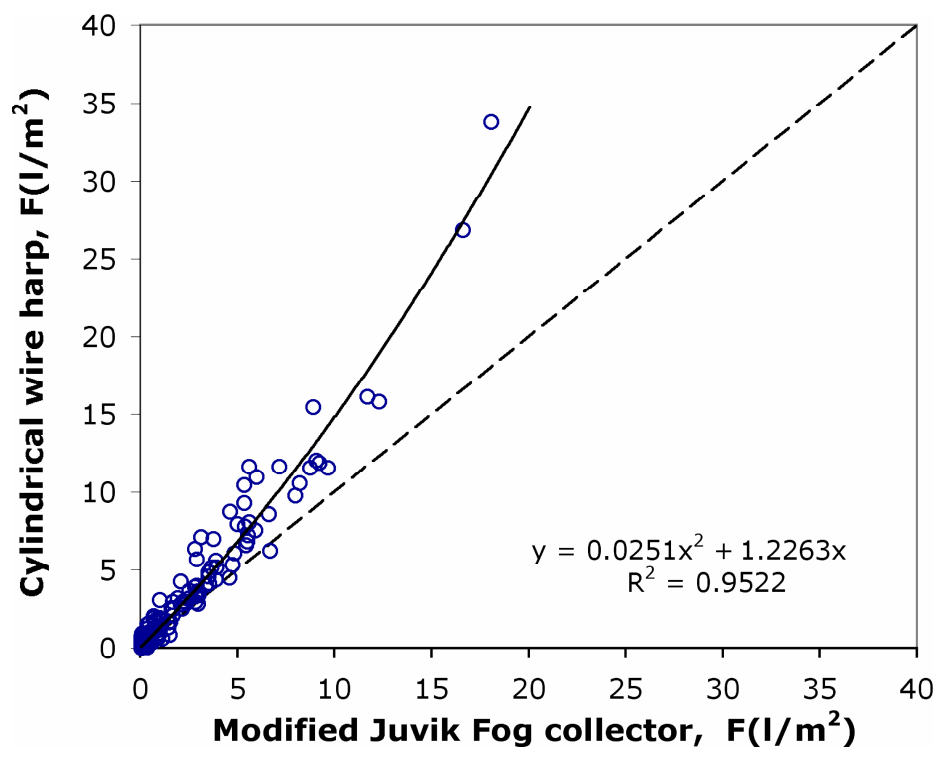

Figure 2. Comparison of daily fog water yields collected in La Esperanza site with the modified Juvik-type and the cylindrical wire-harp fog gauges (1 July 2012 to 25 March 2013).

\section{Results and Discussion}

\subsection{Evolution of the Variables Monitored in the Location of La Esperanza}

Figure $3 \mathrm{a}-\mathrm{f}$ shows the different variables recorded at 15 -min intervals at the site of La Esperanza during the period between 1 July 2012 and 25 November 2013. The total rainfall registered was $1063.4 \mathrm{~mm}$, mainly fallen in the months of October and November 2012. Apart from three of the events, during the rest of the period, rainfall records (at intervals of $15 \mathrm{~min}$ ) did not exceed $5 \mathrm{~mm}$ (Figure 3a). The daily rainfall values are illustrated in Figure $4 \mathrm{a}$ where significant rainfall events exceeding $30 \mathrm{~mm} \cdot \mathrm{d}^{-1}$ were observed. Collected fog water did not represent large amounts, i.e., generally less than $0.4 \mathrm{~L} \cdot \mathrm{m}^{-2}$ in $15 \mathrm{~min}$. From May 2013 onwards, fog water collected with the cylindrical wire harp gauge was not registered due to a failure in the typing bucket gauge (Figure $3 b$ ). This gap in the time series was filled with data obtained from a modified Juvik-type gauge installed in the same scaffolding tower as the cylindrical wire harp gauge (Figure 1b), and that showed similar fog water collection yields (Figure 2 ). The corresponding daily totals are shown in Figure $4 \mathrm{~b}$. These do not exceed $16 \mathrm{~L} \cdot \mathrm{m}^{-2} \cdot \mathrm{d}^{-1}$ except in two cases $\left(26.8\right.$ and $\left.33.8 \mathrm{~L} \cdot \mathrm{m}^{-2} \cdot \mathrm{d}^{-1}\right)$.

February 2013 and July 2012 were the foggiest months in terms of duration of collected water (>125 h/month). By contrast, July 2013 was characterized by a low fog occurrence (15.75 h/month), which highlights the unpredictability of the phenomenon known as fog precipitation. In fact, the summer of 2013 was a dry period with low incidence of both fog and rainfall. The period from November 2012 to January 2013 may be considered a wet period with respect to the fog water collection. Nevertheless, in November 2012, the duration of collected fog water was less than that of rainfall, such that its relative importance as a source of water is hampered (Figure 5a). 

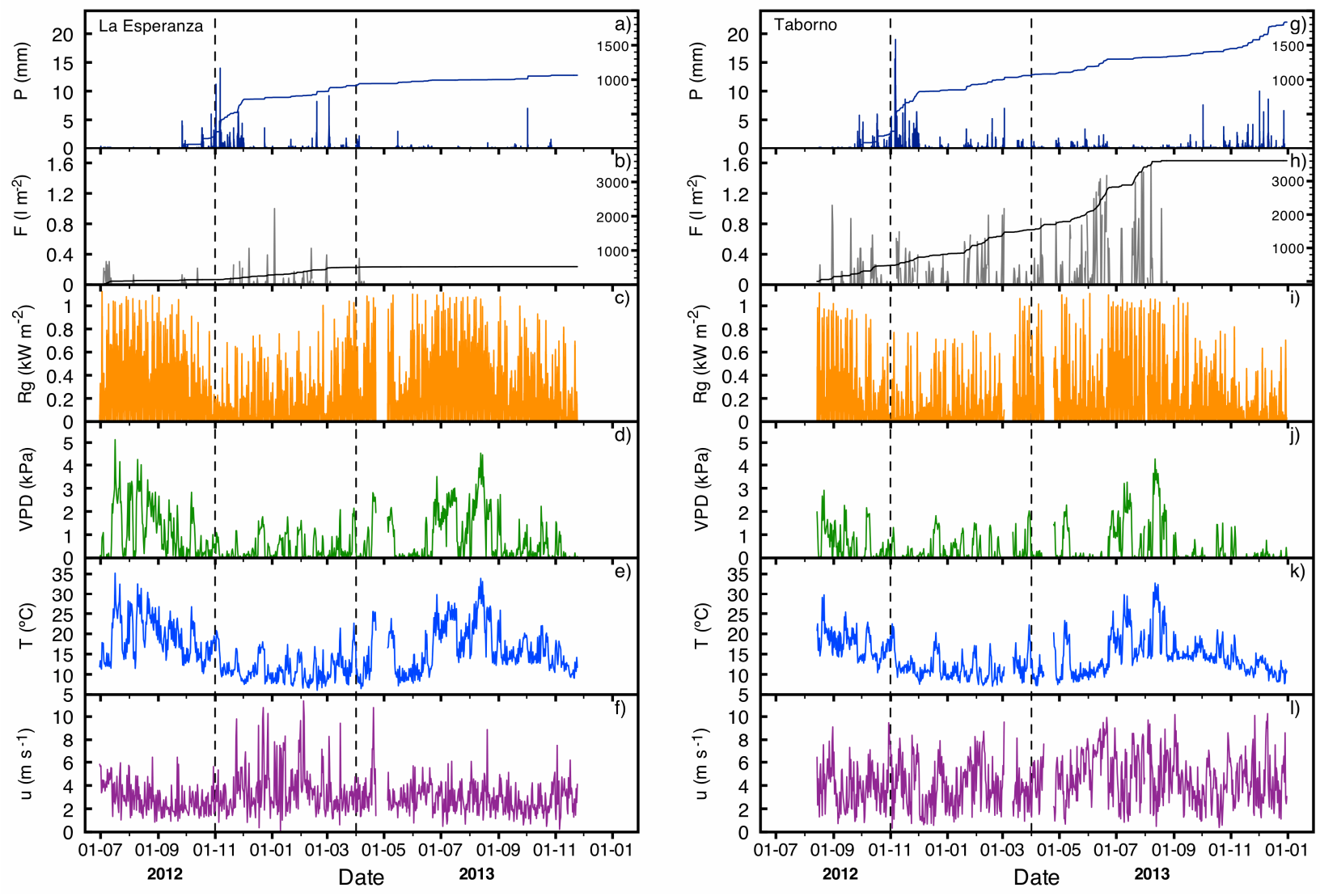

Figure 1. Evolution of the variables recorded during the studied period (La Esperanza: 1 July 2012 to 25 November 2013; Taborno: 15 August 2012 to 31 December 2013). These include $(\mathbf{a}, \mathbf{g})$ rainfall $(\mathrm{P}) ;(\mathbf{b}, \mathbf{h})$ fog water captured in the collector $(\mathrm{F}) ;(\mathbf{c}, \mathbf{i})$ solar radiation $(\mathrm{Rg})$; (d,j) vapor pressure deficit (VPD); (e,k) air temperature (T); and (f,l) wind speed (u). The additional lines and the right hand side axes shown in $(\mathbf{a}, \mathbf{b}, \mathbf{g}, \mathbf{h})$ represent the cumulative values of the corresponding variable.

\subsection{Evolution of the Variables Monitored in the Location of Taborno}

Figure $1 \mathrm{~g}-1$ shows the different variables recorded at 15-min intervals at the site of Taborno. Total precipitation during the period from mid-August 2012 until the end of December 2013 was $1835 \mathrm{~mm}$. Most rainfall events occurred between October-November 2012 and during the months of May-June and November-December 2013 (Figure 3g). The corresponding series of daily rainfall is illustrated in Figure 4c, which includes three days in the period with high rainfall values of $75.2 \mathrm{~mm}$ (18 October 2012), $243.2 \mathrm{~mm}$ (7 November 2012) and $75 \mathrm{~mm}$ (12 November 2013). Fog water collection by the cylindrical wire-harp gauge took place throughout the period (Figures $3 \mathrm{~h}$ and 4d), totaling $157 \mathrm{~L}$ (or $3611 \mathrm{~L} \cdot \mathrm{m}^{-2}$ of vertical surface in $11090 \mathrm{~h}$ ). From September to December 2013, collected fog water was not registered due to a failure in the typing bucket gauge. The amounts of fog water capture observed at 15 -min intervals were generally lower than $1.0 \mathrm{~L} \cdot \mathrm{m}^{-2}$, except in the summer of 2013 where this magnitude was exceeded in some occasions, and the maximum value reached was $1.65 \mathrm{~L} \cdot \mathrm{m}^{-2}$ (Figure 3h). According to the daily totals (Figure 4d) in most of the days with fog events, the recorded values were below $40 \mathrm{~L} \cdot \mathrm{m}^{-2} \cdot \mathrm{d}^{-1}$. One third of total days with fog water collection (168 over 504 days) yielded values higher than $8 \mathrm{~L} \cdot \mathrm{m}^{-2} \cdot \mathrm{d}^{-1}$. Days with the greatest intensity of fog water collection occurred 
during the months of June and July 2013, where a maximum value of $87.5 \mathrm{~L} \cdot \mathrm{m}^{-2} \cdot \mathrm{d}^{-1}$ on 14 June 2013 was recorded (Figure 4d).
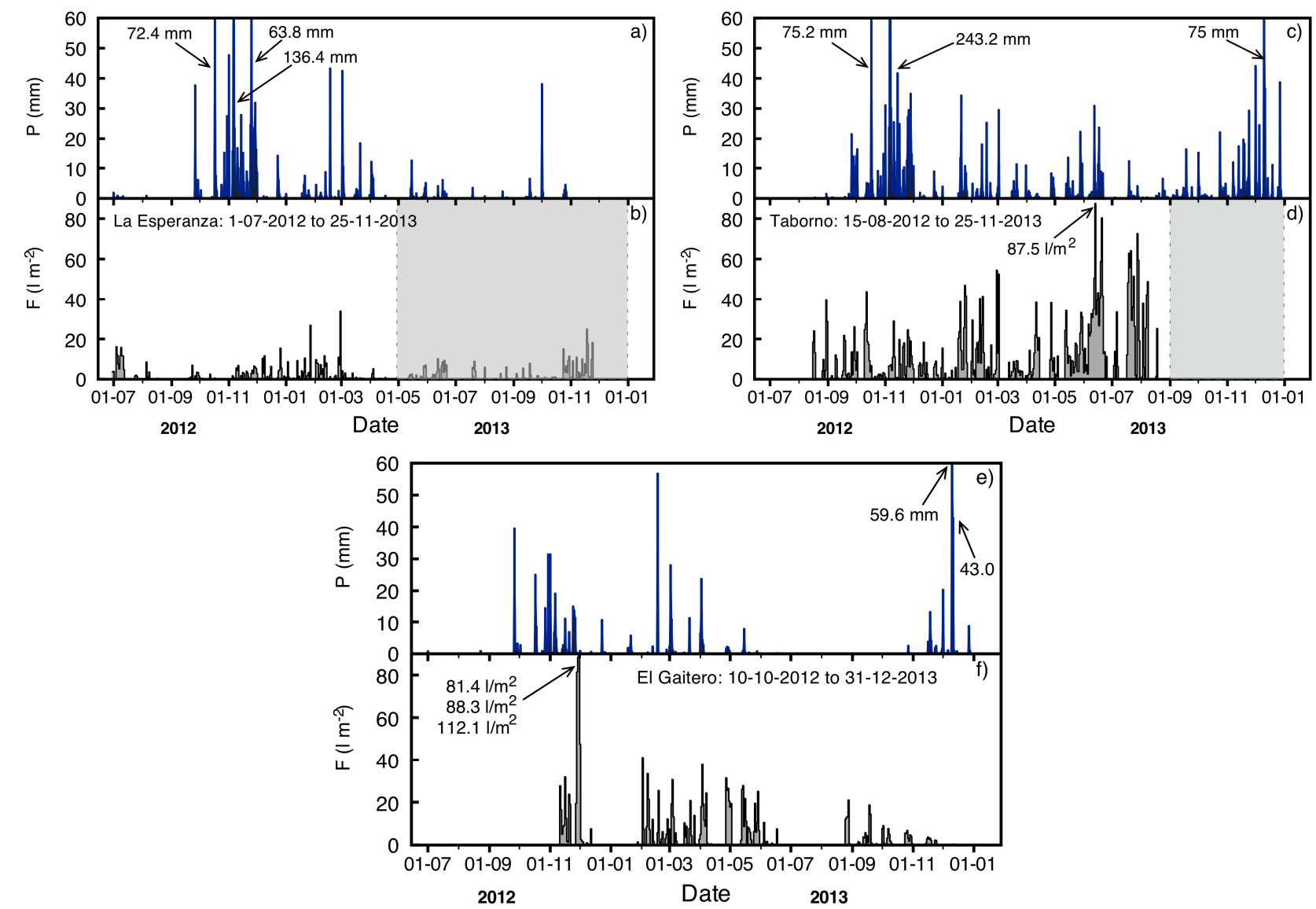

Figure 2. Temporal series of daily rainfall totals $(\mathrm{P})$ fog water collected $(\mathrm{F})$ in La Esperanza $(\mathbf{a}, \mathbf{b})$; Taborno (c,d); and El Gaitero (e,f). Shaded areas in $(\mathbf{b}, \mathbf{d})$ indicate periods during which data from the wire-harp fog gauge were not available.

During the studied period, a total of $2219.25 \mathrm{~h}$ of fog water collection were recorded versus $724.75 \mathrm{~h}$ of rainfall. These times are monthly distributed as shown in Figure 5b. During September 2012 to July 2013, more than $125 \mathrm{~h} /$ month of fog water collection were monitored, reaching in November 2012, February 2012 and May 2013 values higher than 200 h/month. June 2013 was the month with the longest fog water collection period (309 h). By contrast, rainfall hours rarely exceeded the $75 \mathrm{~h} /$ month during the same period, except for November 2012 with $124.75 \mathrm{~h}$ of rainfall. In general, the percentage of hours of rainfall over those when fog water was collected were below $30 \%$. The rainy month of November 2012 was the only one when this percentage reached higher values of $61 \%$. 

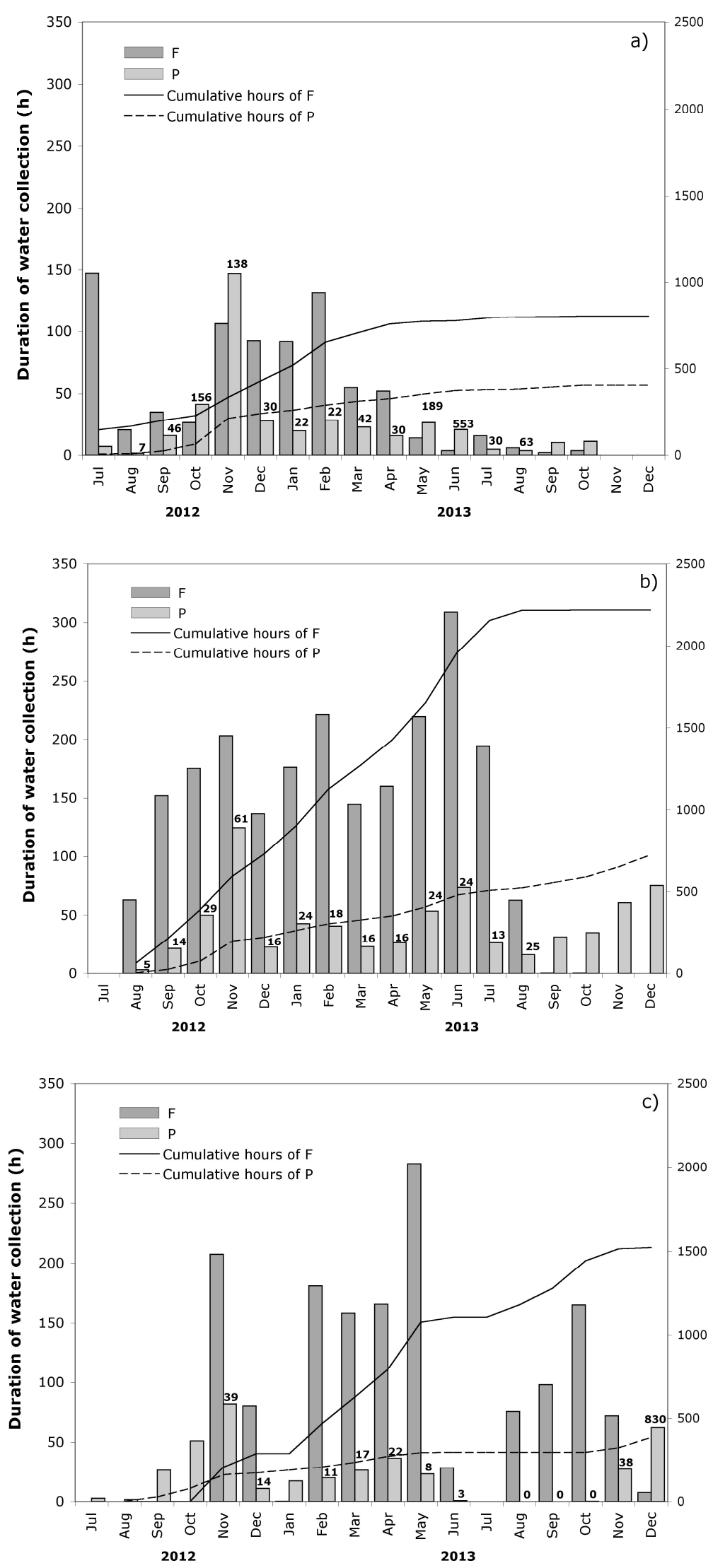

Figure 3. Comparison of the time duration of rainfall and fog water collected during the period studied: (a) La Esperanza; (b) Taborno; and (c) El Gaitero. The numbers shown on top of the bars indicate the percentage of hours of rainfall over those when fog water was collected. The lines and the right hand axes indicate cumulative values. 


\subsection{Comparison of Rainfall and Fog Collection Events in the Location of El Gaitero}

Daily totals of rainfall and water collected by the cylindrical fog collector during the period between 10 October 2012 and 31 December 2013 are shown in Figure 4e-f. Rainfall data were available from a nearby weather station [38]. In January 2013 we also installed a rainfall gauge next to the fog collector to ensure access to our own measurements. Although some rainfall events occurred during late January and mid-May 2013, most rainfall observed during the monitoring campaign took place in Autumn 2012 and 2013. Total precipitation amounts $647.4 \mathrm{~mm}$, where $15.8 \%$ of this rainfall fell on two consecutive days in December 2013 (59.6 mm and $43.0 \mathrm{~mm}$ ) (Figure 4e). At this location, collected fog water was observed at various periods within the measuring period (Figure 3f). Compared with the other locations, fog water collection events in El Gaitero were less frequent but more intense, with typical values higher than $10 \mathrm{~L} \cdot \mathrm{m}^{-2} \cdot \mathrm{d}^{-1}$. Worth mentioning is the period from 28 November 2012 to 6 December 2012 , during which daily maxima of $81.4,88.3$ and $112.1 \mathrm{~L} \cdot \mathrm{m}^{-2} \cdot \mathrm{d}^{-1}$ were reached. These atypical values were also registered in a massive mesh fog collector $\left(1.6 \mathrm{~m}^{2}\right.$ rectangular base and $4 \mathrm{~m}$ high) placed on the ground close to ours (results not shown). These amounts are only comparable to a maximum of $87.5 \mathrm{~L} \mathrm{~m}^{-2} \cdot \mathrm{d}^{-1}$ recorded in Taborno (Figure $4 \mathrm{~d}$ ).

Compared to the duration of rainfall, periods with fog water collection at this location were most frequent (Figure 5c): $1522.75 \mathrm{~h}$ versus $388.5 \mathrm{~h}$. Except for the last month of the monitored period, hours with rainfall represent no more than $31 \%$ of those with fog water collection. In six of the months during the period, duration of fog water collection outranged the $125 \mathrm{~h}$. In May 2013 a total of $283 \mathrm{~h}$ with fog water collection versus only $23.25 \mathrm{~h}$ with rainfall were observed. The four-month period between February and May 2013 proved to be particularly important in terms of fog water capture, with $788 \mathrm{~h}$ versus only $106.25 \mathrm{~h}$ with rainfall.

\subsection{Comparison of the Three Sites in Terms of Collected Fog Water}

In order to compare the three measuring sites in terms of their potential for capturing fog water artificially, we have chosen the period from 1 November 2012 to 31 March 2013, because during this time interval data obtained from the cylindrical fog collector were available at the three locations. The evolution of the daily totals is shown in Figure 4. In La Esperanza (at an altitude of $1093 \mathrm{~m}$ a.s.1.), fog water harvesting occurs frequently during the period, but is considerably lower than in the other two locations. The total fog yields value for this period amounted to $357.7 \mathrm{~L} \cdot \mathrm{m}^{-2}$ in La Esperanza, while in Taborno (1015 $\mathrm{m}$ a.s.1.) and El Gaitero (1747 $\mathrm{m}$ a.s.1.) this was much higher, $1065.1 \mathrm{~L} \cdot \mathrm{m}^{-2}$ and $868.3 \mathrm{~L} \cdot \mathrm{m}^{-2}$, respectively. However, while in Taborno fog water collection episodes were distributed throughout the period, in El Gaitero these are mainly concentrated in two periods (November-December 2012 and February-March 2013). Collection intensities in La Esperanza were generally below $10 \mathrm{~L} \cdot \mathrm{m}^{-2} \cdot \mathrm{d}^{-1}$ except for three days with higher values, i.e., $15.4,26.8$ and $33.8 \mathrm{~L} \cdot \mathrm{m}^{-2} \cdot \mathrm{d}^{-1}$. In Taborno, during the observed period corresponding to 2012, collection intensities were below $20 \mathrm{~L}$ $\mathrm{m}^{-2} \cdot \mathrm{d}^{-1}$, while in 2013 this was $40 \mathrm{~L} \cdot \mathrm{m}^{-2} \cdot \mathrm{d}^{-1}$. However, the latter was exceeded in some events taken place at the end of January, mid of February and beginning of March 2013. Analogously, in El Gaitero a value of approximately $40 \mathrm{~L} \cdot \mathrm{m}^{-2} \cdot \mathrm{d}^{-1}$ could be established, but this was considerably exceeded at events occurring at the end of November with a maximum observed of $112.1 \mathrm{~L} \cdot \mathrm{m}^{-2} \cdot \mathrm{d}^{-1}$. These 
variations in fog water capture observed in the different locations may be related to the weather conditions at each site, which are determined by their location. The study of the relationship between the fog water harvesting and the daily averages of meteorological variables does not provide any clear relationship (Figure 6), but it suggests that the greater volumes of collected fog water are logically associated with higher wind speeds and lower solar radiation conditions. Figure 6 shows also that fog water collection in La Esperanza and in Taborno typically occurs within a temperature interval of approximately $7.5-12.5{ }^{\circ} \mathrm{C}$, while in El Gaitero the phenomenon is associated with a lower temperature interval (approximately $2.5-10^{\circ} \mathrm{C}$ ). This may be attributed to the higher altitude of the latter site.

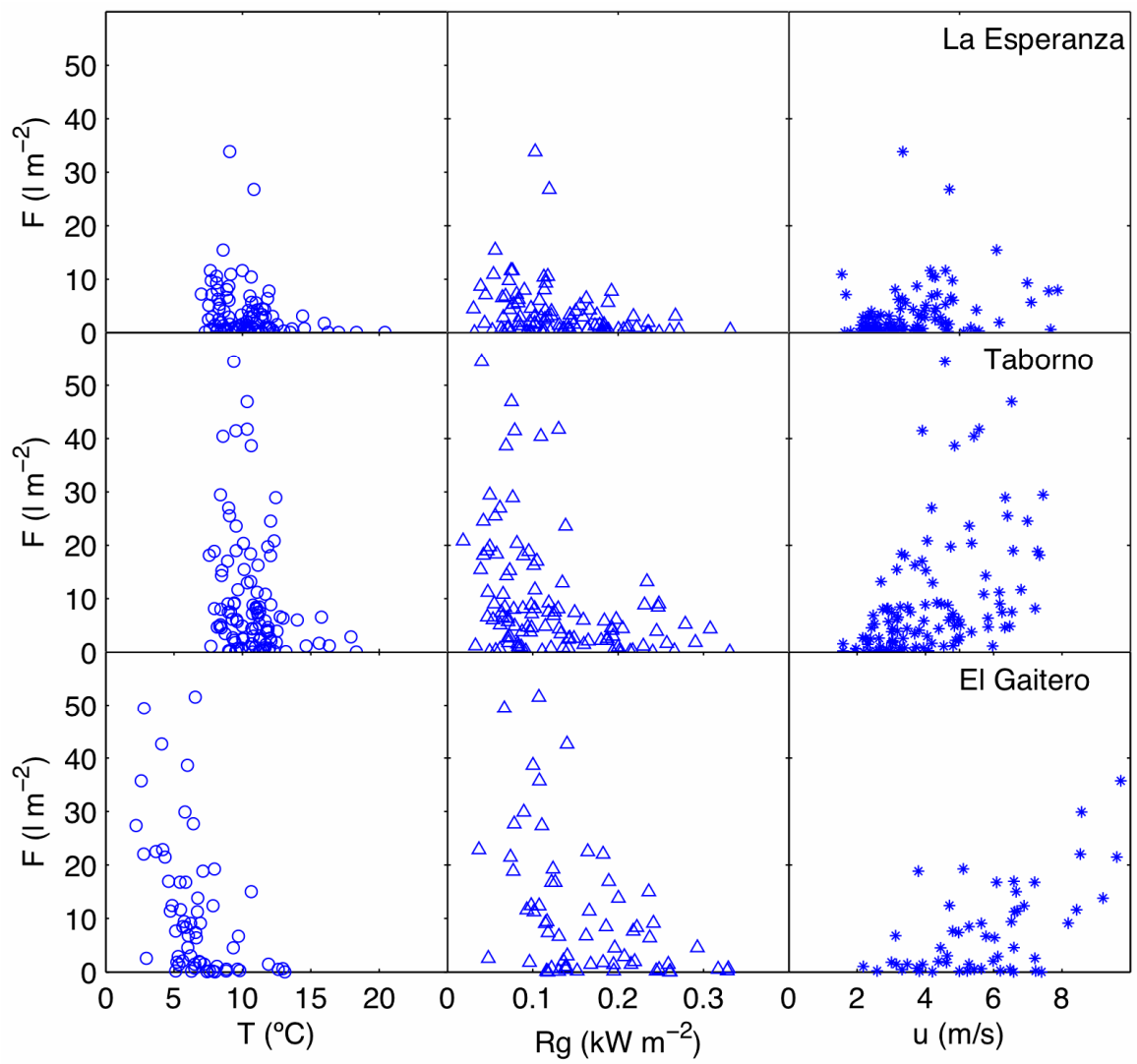

Figure 4. Daily totals of fog water collection (F) versus daily averages of temperature (T), solar radiation $(\mathrm{Rg})$, and wind speed $(\mathrm{u})$ at the three locations during the period 1 November 2012 to 31 March 2013.

\section{Conclusions}

In general, and according to the number of recorded events, fog water collection proved to be more frequent than rainfall at the three monitoring sites. The volumes of captured fog water varied among the different sites studied: while in some locations daily intensities were generally below $10 \mathrm{~L} \cdot \mathrm{m}^{-2}$ of cross sectional vertical surface (with an absolute maximum of $33.8 \mathrm{~L} \mathrm{~m}^{-2} \cdot \mathrm{d}^{-1}$ ), greater values were observed in the highest site, where a daily maximum of $112.1 \mathrm{~L} \cdot \mathrm{d}^{-1} \cdot \mathrm{m}^{-2}$ vertical surface was recorded. During a comparative nine-months period, the total amounts of collected fog water in the three studied sites were $468.3,506.5$ and $350.6 \mathrm{~L} \cdot \mathrm{m}^{-2}$ cross sectional vertical surface. A characteristic feature of the fog water harvesting process is that its potential use as a water source depends on the local 
meteorological conditions. Water quality is an additional issue to also be taken into account and not investigated here, if this is to be destined to human consumption [26]. In consequence, previous studies on fog water capture, similar to the one described in this work, are recommended in order to determine to what extent it may represent a reliable resource (i.e., available throughout the period that it is required as a water source), sufficient (i.e., a minimal infrastructure guarantees relevant fog water yields) and viable (i.e., it is economically profitable and its implementation is practical).

\section{Acknowledgments}

Data used in this study were collected under the INIA-RTA2009-161 and CajaCanarias Fundación Agua.09.ECANSA research projects. Additional financial support was also obtained from INIA-RTA2013-88 research project. The authors want to thank the Spanish Agency Aeropuertos Españoles y Navegación Aérea (AENA) for allowing access to their facilities in Taborno, to Sieltec Canarias S.L. and to Theo Hernando Olmo for their technical support, and to Agrocabildo (Tenerife Government Agency) for providing the meteorological data at the El Gaitero location.

\section{Author Contributions}

Axel Ritter was mainly responsible for the field installation of the instrumentation, data analysis, elaboration of graphics and paper writing. Carlos M. Regalado contributed in the data collection, instrumentation, discussion of results and writing. Juan C. Guerra provided support in the installation of the field equipment in Taborno, and made some modifications in the manuscript.

\section{Conflicts of Interest}

The authors declare no conflict of interest.

\section{References}

1. Guerra, J.C.; Carrillo, J.; Rodríguez, J.; Arencibia, M.T.; Cuevas, E. Thermodynamic Structure of the Lower Subtropical Troposphere over the Canary Islands. In Proceedings of the 7th Annual Meeting of the European Meteorological Society, El Escorial, Madrid, Spain, 1-5 October 2007.

2. Font Tullot, I. El tiempo atmosférico de las Islas Canarias. In Publicaciones del Servicio Nacional de Meteorología; Serie A (Memorias No. 26); Servicio Meteorológico Nacional (INM): Madrid, Spain, 1956, 15-23.

3. Cuevas, E. Estudio del comportamiento del ozono troposférico en el observatorio de Izaña (Tenerife) y su relación con la dinámica atmosférica. Ph.D. Thesis, Universidad Complutense de Madrid, Madrid, Spain, 1995.

4. Rodríguez, S. Comparación de las Variaciones de Ozono Superficial Asociadas a Procesos de Transporte Sobre y bajo la Inversión de Temperatura Subtropical en Tenerife. MSc Dissertation, University of La Laguna, Tenerife, Canary Islands, Spain, 1999. 
5. Aboal, J.R.; Regalado, C.M.; Ritter, A.; Gómez, L.A.; Fernández, A.B. Interceptación de Lluvia y Niebla en Bosques de Laurisilva y pinar de las Islas Canarias. In Interceptación de la Lluvia por la Vegetación en España; Belmonte Serrato, F., Romero Díaz, A., Eds.; Fundación Instituto Euromediterráneo del Agua: Murcia, Spain, 2013, 47-78. Available online: http://www.icia.es/ icia/download/suelosyriegos/Libro_Aboal-CAPITULO1.pdf (accessed on 17 June 2015).

6. Ritter, A.; Regalado, C.M.; Aschan, G. Fog water collection in a subtropical elfin laurel forest of the Garajonay National Park (Canary Islands): A combined approach using artificial fog catchers and a physically-based impaction model. J. Hydrometeorol. 2008, 9, 920-935.

7. Ritter, A.; Regalado, C.M.; Aschan, G. Fog reduces transpiration in tree species of the Canarian relict heath-laurel cloud forest (Garajonay National Park, Spain). Tree Physiol. 2009, 29, 517-528.

8. Gischler, C. Atrapanieblas para fertilizar el desierto. Iberica 1982, 230, 53-55.

9. Gischler, C.; Fernández Jáuregui, C. Técnicas económicas para la conservación y gestión del agua en América Latina. Nat. Recur. 1984, 20, 11-18.

10. Lleal, F. La Camanchaca. Captaciones de agua en el desierto de Atacama. Riegos Drenajes 1991, 49, 33-49.

11. Ritter, A.; Regalado, C.M. Comment on García-Santos, G.; Bruijnzeel, L.A. 2011 Rainfall, fog and throughfall dynamics in a subtropical ridge top cloud forest, National Park of Garajonay (La Gomera, Canary Islands, Spain). Hydrol. Process. 2013, 27, 1123-1128.

12. Glickman, T.S. Glossary of Meteorology, 2nd ed.; American Meteorological Society: Boston, MA, USA, 2000.

13. Klemm, O.; Wrzesinsky, T.; Scheer, C. Fog water flux at a canopy top: Direct measurement versus one-dimensional model. Atmos. Environ. 2005, 39, 5375-5386.

14. Ide, R.F. Comparison of Liquid Water Content Measurement Techniques in an Icing Wind Tunnel. NASA Technical Memorandum; National Aeronautics and Space Administration: Washington, DC, USA, 1999.

15. Eugster, W.; Burkard, R.; Holwerda, F.; Scatena, F.N.; Bruijnzeel, L.A. Characteristics of fog and fogwater fluxes in a Puerto Rican elfin cloud forest. Agric. For. Meteorol. 2006, 139, 288-306.

16. Shuttleworth, W.J. The exchange of wind-driven fog and mist between vegetation and the atmosphere. Bound. Layer Meteorol. 1977, 12, 463-489.

17. Nagel, J.F. Fog precipitation on Table Mountain. Q. J. R. Meteorol. Soc. 1956, 82, 452-460.

18. Skarżyńska, K.; Polkowska, Ż.; Namieśnik, J. Sampling of atmospheric precipitation and deposits for analysis of atmospheric pollution. J. Autom. Methods Manag. Chem. 2006, 26908, 1-19.

19. Frumau, K.F.A.; Burkard, R.; Schmid, S.; Bruijnzeel, L.A.; Tobón, C.; Calvo-Alvarado, J.C. A comparison of the performance of three types of passive fog gauges under conditions of wind-driven fog and precipitation. Hydrol. Process. 2011, 25, 374-383.

20. Holwerda, F.; Bruijnzeel, L.A.; Scatena, F.N. Comparison of passive fog gauges for determining fog duration and fog interception by a Puerto Rican elfin cloud forest. Hydrol. Process. 2011, 25, 367-373.

21. Goodman, J. The collection of fog drip. Water Resour. Res. 1985, 21, 392-394.

22. Bruijnzeel, L.A.; Proctor, J. Hydrology and Biochemistry of Tropical Montane Cloud Forests: What do We Really Know? In Tropical Montane Cloud Forests. Ecological Studies; Hamilton, L.S., Juvik, J.O., Scatena, F.N., Eds.; Springer-Verlag: New York, NY, USA, 1998; pp. 38-78. 
23. Bruijnzeel, L.A. Hydrology of tropical montane cloud forests: A Reassessment. Land Use Water Res. 2001, 1, 1.1-1.18.

24. Schemenauer, R.S.; Cereceda, P. Fog collection's role in water planning for developing countries. Nat. Resour. Forum 1994, 18, 91-100.

25. Rivera, J.D.; López-García, D. Mechanical characteristics of Raschel mesh and their application to the design of large fog collectors. Atmos. Res. 2015, 151, 250-258.

26. Klemm, O.; Schemenauer, R.S.; Lummerich, A.; Cereceda, P.; Marzol, V.; Corell, D.; van Heerden, J.; Reinhard, D.; Gherezghiher, T.; Olivier, J.; et al. Fog as a fresh-water resource: Overview and perspectives. AMBIO 2012, 41, 221-234.

27. García Prieto, P. Informe. Sobre. Observaciones. de Captación de Agua Directamente de las Nubes por Medio de Telas. Metálicas Efectuadas. en el observatorio de Izaña (Tenerife); Servicio Meteorológico Nacional: Madrid, Spain, 1962.

28. Santana Pérez, L.M. Estudio de la Precipitación de Niebla en Tenerife; ICONA. Santa Cruz de Tenerife, Spain, 1986, 1-97.

29. Marzol Jaen, M.V. Fog water collection in a rural park in the Canary Islands (Spain). Atmos. Res. 2002, 64, 239-250.

30. Morey, M.; González, F. Aspectos de la utilización del agua por las plantas en las Islas Canarias. Bol. Real Soc. Española Historia Nat. Biol. 1966, 64, 369-383.

31. Kämmer, F. Klima und Vegetation auf Tenerife, besonders im Hinblick auf den Nebelniederschlag. Scr. Geobot. 1974, 7, 1-78.

32. Santana Pérez, L.M. La precipitación de niebla en Tenerife. Agrocabildo. Available online: http://www.agrocabildo.org/publica/analisisclimatico/precipitacion_en_niebla.pdf (accessed on 17 June 2015).

33. Mohnen, V.A.; Kadlecek, J.A. Cloud chemistry research at Whiteface Mountain. Tellus B 1989, 41, 79-91.

34. Schemenauer, R.S. Acidic deposition to forests: The 1985 Chemistry of High Elevation Fog Project. Atmos. Ocean 1986, 24, 303-328.

35. Demoz, B.; Collett, J.L., Jr.; Daube, B.C., Jr. On the Caltech active strand cloudwater collectors. Atmos. Res. 1996, 41, 47-62.

36. Park, K.C.; Chhatre, S.S.; Srinivasan, S.; Cohen, R.E.; McKinley, G.H. Optimal design of permeable fiber network structures for fog harvesting. Langmuir 2013, 29, 13269-13277.

37. Rivera, J.D. Aerodynamic collection efficiency of fog water collectors. Atmos. Res. 2011, 102, 335-342.

38. Agrocabildo. Listado de estaciones agrometeorológicas. Available online: http://www.agrocabildo.org/agrometeorologia_estaciones_detalle.asp?id=7 (accessed on 17 June 2015).

(C) 2015 by the authors; licensee MDPI, Basel, Switzerland. This article is an open access article distributed under the terms and conditions of the Creative Commons Attribution license (http://creativecommons.org/licenses/by/4.0/). 